〈調查報告〉

\title{
原油湧出土から単離した菌株によるナフタレンの代謝
}

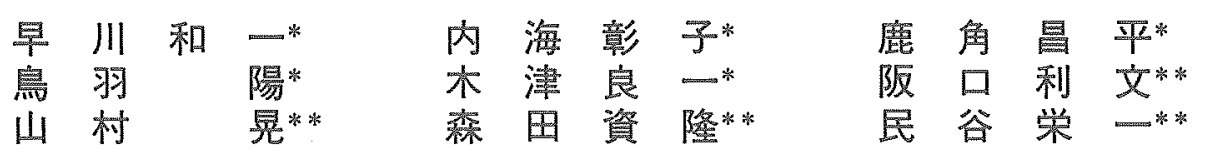

\section{Metabolism of Naphthalene in Bacterial Strains Isolated from Oil Well Soils}

\author{
Kazuichi HAYAKAWA*, Akiko UTSUMI*, Shohei KATSUNO*, \\ Akira TORIBA*, Ryoichi KIZU*, Toshifumi SAKAGUCHI**, \\ Akira YAMAMURA**, Yasutaka MORITA** and Eiichi TAMIYA** \\ * Faculty of Pharmaceutical Sciences, Kanazawa University, 13-1, Takara-machi, Kanazawa 920-0934 Japan \\ * Japan Advanced Institute of Science and Technology, Hokuriku, 1-1, Asahidai, Tatsunokuchi, Ishikawa 923-1292 \\ Japan
}

\begin{abstract}
Two bacterial strains, $\mathrm{N}-21$ and $\mathrm{N}-22$, which were isolated from natural oil-producing wells at Kurokawa, Niigata Prefecture, Japan, were identified as Pseudomonas cepacia by using the phylogenetic analysis based on the 16SrDNA sequences. Both strains were gram negative rods capable of decomposing naphthalene. The degradation rates were $2.24 \times 10^{-5} \mathrm{M} / \mathrm{h}$ in both strains. The main metabolite was cis-1,2-dihydro-1,2-naphthalenediol. Salicylaldehyde, salicylic acid, gentistic acid and catechol were also identified. These metabolites were less mutagenic than naphthalene itself in the Ames test using the S. typhimurium TA100 strain. The mutagenicity of naphthalene also decreased by the two bacterial strains.
\end{abstract}

Key words : naphthalene, bacteria, metabolism, bioremediation, mutagenicity

\section{1.はじめに}

多環芳香族炭化水素 (PAH) は広く環境中に存在して

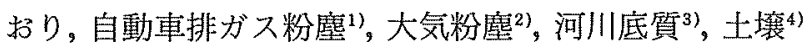
などから検出されている。またPAH は原油にも含まれ て扔り，1997年1月 2 日に発生した十ホ卜力号重油流出 事故の際は，漂着重油に含まれるPAH の生態系への影 響やヒトの健康影響が懸念された。ナフタレン（Nap） はPAH の中でも最も簡単な構造の化合物で，ナホトカ 号から流出した重油に含まれるPAHのなかでは最も含 量の高い成分であったら。またナフタレンは，衣類の防虫 剤などとして汎用される身近な薬品でもある。急性毒性 としては溶血性貧血及び腎毒性, 慢性毒性としては白内 障及び網膜障害が報告されているが，発癌性については 確認されていない6-10)。

一方，バイオレメディエーションは污染された環境の 有効な修復手段の一つとして考えられており，油に污染 された環境の浄化法として有望視されている。既にNap を含むいくつかの $\mathrm{PAH}$ を分解する菌が発見されている が11-14)，環境中にはより分解能の高い未知の菌が存在す
ると期待され，細菌の検索が望まれる。そこで本研究で は，まず原油湧出地である新潟県北蒲原郡黒川村のシン クルトン記念公園の土裹加ら 2 種類の Nap 分解菌を単 離した。次いで，それらによるNap 代謝過程における生 成物の同定と変異原性試験を行い, 単離した菌の有用性 を評価した。

\section{2. 寅験方法}

\section{1 試薬及び装置}

Nap 及びゲンチシン酸は関東化学製特級, サリチルア ルデヒド，サリチル酸及びカテコールはナカライテスク 製特級，シス-1,2-ジヒドロ-1,2-ナフタレンジオールは シグマ製,メタノールは和光純薬工業製 HPLC 用を使用 した。水は Milli-Q Plus（ミリポア）によって精製した 超純水を使用した。

遠心分離器は MICRO 6 CMF-100 (イワキ), 位相差 型光学顕微鏡は OPTIPHOT-2 (ニコン), 透過型電子顥 微鏡は H-7100 (日立)，キャピラリ一電気泳動型 DNA シークエンサーは PRISM ${ }^{\mathrm{TM}} 310$ Genetic Analyzer (ABI)を使用した。HPLCシステムの構成は以下の通り 
である。ポンプ；880-PU (日本分光)，ミキシングモ ジュール；880-30 (日本分光)，デガッサー；DGU-14A

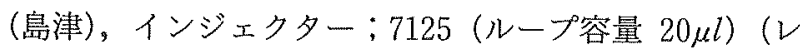
オダイン)，紫外可視吸光度検出器：SPD-10A (島津) 及 び MD-910 (日本分光)，インテグレーター；C-R7A (島 津)。LC-MS は LCQ (Finnigan MAT) を使用した。

2.2 HPLC 及びLC-MS 条保

\subsubsection{HPLC}

分析力ラムはコスモシール 5C18-MS (4.6 mm i.d. $\times$ $250 \mathrm{~mm}$ ) (ナカライテスク),ガードカラムはコスモシー ル5C18-MS (4.6 mmi.d. × $10 \mathrm{~mm}$ )(ナカライテスク) を用いた。カラム温度は室温 $\left(20 \pm 1{ }^{\circ} \mathrm{C}\right)$ とした。移 動相条件は次の通りである。Nap 分解速度試験にはメ夕 ノール：䣫酸水溶液 $(\mathrm{pH} 3.0)(7: 3, \mathrm{v} / \mathrm{v})$ を用いて, イソクラティック溶離条件とした。代謝物の同定とその 経時変化の追跡にはメタノ一ルと酢酸水溶液 ( $\mathrm{pH} 3.0)$ を用いて，メ夕ノール20\% ( $0 \mathrm{~min}$ ) から90\% (30 min) までのリニアグラジエント条件とした。いずれも流速は $1.0 \mathrm{~m} l \cdot \mathrm{min}^{-1}$, 検出波長は275 $\mathrm{nm}$ とした。

\subsubsection{LC-MS}

分離力ラムは Mightysil RP-18（2.0 mm i.d. × 250 $\mathrm{mm}: 5 \mu \mathrm{m}$ ) (関東化学) を用い，力ラム温度は $40^{\circ} \mathrm{C}$ と した。移動相条件は次の通りである。シス-1,2-ジヒドロ -1,2-ナフタレンジオール及びサリチルアルデヒドの分 析にはメタノール一酷酸緩衝液（3：7，v/v)，サリチ ル酸，カテコール，ゲンチシン酸の分析にはメタノール 一酭酸緩衝液（1：9，v/v）をいずれもアイソクラ ティック条件で用いた。䣫酸緩衝液は10 mM 酶酸アン モニウム水溶液に酿酸を $0.1 \%(\mathrm{v} / \mathrm{v})$ となるように加

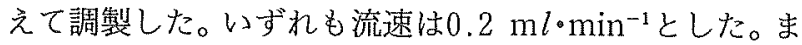
たMSにおけるイオン化法はESI 用いた。

\section{3 供試培地及び培萺条仵}

菌の培養に分離培地 $\left(\mathrm{KH}_{2} \mathrm{PO}_{4} 0.2 \mathrm{~g}, \mathrm{~K}_{2} \mathrm{HPO}_{4} 0.8\right.$ $\mathrm{g}, \mathrm{NH}_{4} \mathrm{NO}_{3} 0.2 \mathrm{~g}, \mathrm{MgSO}_{4} \cdot 7 \mathrm{H}_{2} \mathrm{O} 0.5 \mathrm{~g}$ ，酵母抽出物 $0.01 \mathrm{~g}$, 無機塩溶液 $4.0 \mathrm{~m} l$, 蒸留水 $1.0 l$, アガ一粉末 $15.0 \mathrm{~g})$ を使用し，必要に応じて Napやグルコース等を 添加した。無機塩溶液の組成は $\mathrm{N}\left(\mathrm{CH}_{2} \mathrm{COOH}\right)_{3} 3.0 \mathrm{~g}$, $\mathrm{MgSO}_{4} \cdot 7 \mathrm{H}_{2} \mathrm{O} 6.0 \mathrm{~g}, \mathrm{MnSO}_{4} \cdot \mathrm{H}_{2} \mathrm{O} 1.0 \mathrm{~g}, \mathrm{NaCl} 2.0$ $\mathrm{g}, \mathrm{FeSO}_{4} \cdot 7 \mathrm{H}_{2} \mathrm{O} 0.2 \mathrm{~g}, \mathrm{CoCl}_{2} \cdot 6 \mathrm{H}_{2} \mathrm{O} 0.2 \mathrm{~g}, \mathrm{CaCl}_{2} 0.2$ g, $\mathrm{ZnSO}_{4} \cdot 7 \mathrm{H}_{2} \mathrm{O} 0.02 \mathrm{~g}, \mathrm{CuSO}_{4} \cdot 7 \mathrm{H}_{2} \mathrm{O} 0.02 \mathrm{~g}$, AlK $\left(\mathrm{SO}_{4}\right)_{2} \cdot 12 \mathrm{H}_{2} \mathrm{O} 0.02 \mathrm{~g}, \mathrm{H}_{3} \mathrm{BO}_{3} 0.02 \mathrm{~g}, \mathrm{Na}_{2} \mathrm{MoO}_{4} 0.02$ $\mathrm{g}$ ，蒸留水 $1.0 l$ とした。加熱隇菌した分離培地 $20 \mathrm{~m} l$ に ポリペプトン $\left(0.05 \mathrm{~g} \cdot l^{-1}\right)$ 及び Nap $(0.5 \mathrm{~g})$ を添加 し,単離された Nap 分解菌の 1 コロニーを接種して三角 フラスコで前培養を行った。その菌液を最終濃度が $1 \times$ $10^{6} \mathrm{cells} \cdot \mathrm{m} l^{-1}$ になるうに分離培地 $20 \mathrm{~m} l$ と Nap $0.05 \mathrm{~g}$ の入った角フラスコに加え, $27^{\circ} \mathrm{C}, 140 \mathrm{rpm} て ゙$ 振とう培養した。培養液の一部をとり、これに等量のメ タノールを加えて菌による代謝を停止させた。

Nap 分解菌の分離は次のように行った。まず少量のへ キサンに溶解した Nap 溶液を分離培地プレート上に染 布した寒天培地を作成し，風乾した。次に，調製した寒 天培地に石油涌出地から得られた土壤懸濁液を線画し， 生じたコロニーを採取した。

\subsection{Nap 分解第の同定}

Nap 分解菌の同定には，グラム染色，オキシダーセ，
カタラーゼ活性試験，及び API 簡易同定キット（Biomerieux）を用いた。また，リンタングステン酸でネガ ティブ染色した菌体の形態観察を透過型電子顕微鏡を用 いて行った。さらに分子系統分類のために，アルカり法 によって菌体中から DNA を抽出し，PCR 法を用いて16 SrDNA を選択的に增幅した。得られた菌株の16SrDNA の増幅には大腸菌 Escherichia coli の16SrDNA ポジ ション 8〜25及び1523〜1542に相当するプライマーをデ ザインし ${ }^{15)}$, 約 $1.5 \mathrm{kbp}$ の增幅 DNA 断片を得た。さらに, 增幅した16SrDNAをテンプレートとして，キャピラ リ一電気泳動型 DNA シークエンサーを用いて，サイク ルシータエンス，ダイターミネーター法により遺伝子配 列を決定し，FASTA プログラムに基づいて近縁種との 相同性を検索した。

\section{$2.5 \mathrm{Nap}$ 分解菌の炭添資化試験}

単離したそれぞれの菌について,2.3の方法で前培昱を 行い, さらに $25^{\circ} \mathrm{Cで} 1$ 週間振とう培養した。必要に応じ て繁留水で希釈し，へモサイトメーターを用いて位相差 型光学蹎微鏡で菌数を計測した。

\subsection{Nap 分解菌に上るNap 分解速度試験}

Nap の揮発や菌体膜への吸着などの影響を除くため に，2.30方法に加えてポリペプトン $\left(0.05 \mathrm{~g} \cdot \mathrm{l}^{-1}\right)$ 及び グルコース $\left(0.5 \mathrm{~g} \cdot l^{-1}\right)$ 涯加培地でも前培養を行った。 菌による $\mathrm{Nap}$ 分解速度定数は初期相の反応を 0 次反応 と仮定し, 菌を含む培地と含まない培地の Nap 濃度の差 から求めた。分解速度試験の際にはDMSO に溶解した Nap 溶液を加え, Nap 濃度 $1 \times 10^{-4} \mathrm{M}$, DMSO 濃度 $1 \%$ としたまた菌の初期濃度は $1 \times 10^{8} \mathrm{cells} \cdot \mathrm{m} l^{-1}$ とした。メタノールを加えて反応を停止させた後に超音 波処理 (5 min)，遠心 (5 min) を順次行い，その上清 の一部を HPLCに注入した。

\section{7 代謝物の同定と経時变化}

単離したそれぞれの菌について，2.50方法に従ってポ リペプトン $\left(0.05 \mathrm{~g} \cdot l^{-1}\right)$ 及び Nap $(0.5 \mathrm{~g})$ を添加し

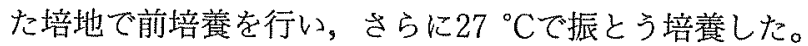
メタノールを加充て反応を停止させた後に超音波処理 (5 min)，遠心 (5 min) 順次行い，その上清の一部 をHPLCに注入した。LC-MS 分析時には44時間培屓し た試料を使用した。

\subsection{Nap 及びその代謝物の变異原性試験}

変異原性試験は Ames 法 (Salmonella typhimurium TA100 秼)により行った。対照としては試験試料の代わ りにDMSOを，陽性対照として直接変異原性試験では 2-ニトロフルオランテンを，間接変異原性試験では benzo[a]pyreneを使用した。さらに試験菌の死隇 (killing）の影響を除くため，別途に生菌数を測定して復帰突 然变異数を補正した。

\section{3．結果及び考察}

\subsection{Nap 分解菌の算離と同定}

Napのみを添加した分離培地中で増殖が認められた 菌株について，継代培㽰によって菌の純化を行ったとこ ろ， 2 種類の Nap 分解菌 (以後, これらの菌を N-21株 及びN-22株とする) を粆離できた。

16SrDNA の塩基配列に基づく系統分類の結果，両 菌株から增幅された約 $1.5 \mathrm{kbp}$ の $16 \mathrm{SrDNA}$ はをに 

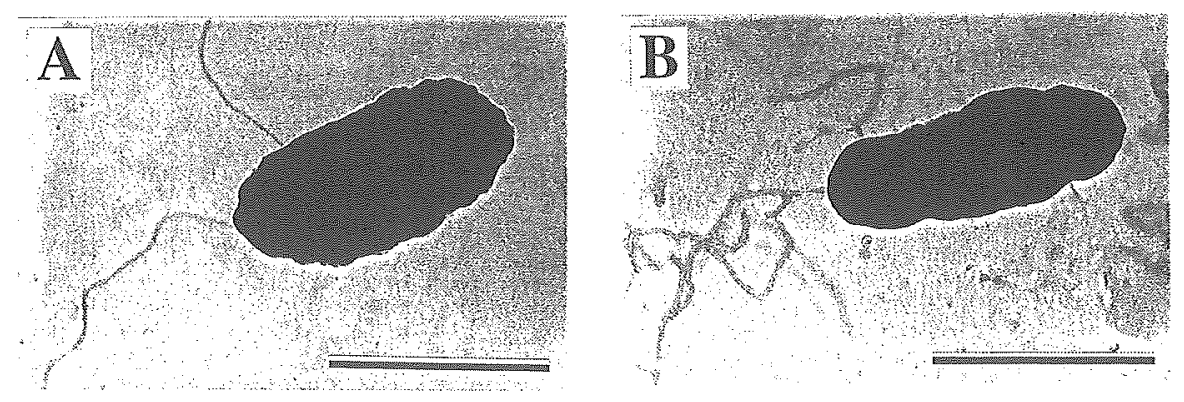

Fig. 1 Transmission Electron Micrographs of Naphthalene Degrading Bacteria Strains, (A) N-21 and (B) N-22, Isolated from a Natural Oil Producing Well at Kurokawa, Niigata

Cells were negatively stained with $1 \%$ sodium phosphotungstate solution. Bars indicate $1.0 \mu \mathrm{m}$.

Table 1 AP120 Test of N-21 and N-22 Strains

\begin{tabular}{|c|c|c|}
\hline Trait & $\mathrm{N}-21$ & $\mathrm{~N}-22$ \\
\hline Gram strain & - & - \\
\hline Oxidase & - & - \\
\hline Catalase & - & - \\
\hline Nitrate reduction (Nitrite production) & - & - \\
\hline B-Galactosidase & - & - \\
\hline Argine dehydrogenase & + & - \\
\hline Lysine decarboxylase & + & + \\
\hline Ornithine decarboxylase & - & - \\
\hline Citrate utilization & + & + \\
\hline $\mathrm{H} 2 \mathrm{~S}$ production & - & - \\
\hline Urease & - & - \\
\hline Tryptophan deaminase & - & - \\
\hline Indole production & - & - \\
\hline Acetoin production & - & - \\
\hline Gelatinase & + & + \\
\hline \multicolumn{3}{|l|}{ Utilization } \\
\hline Glucose & + & + \\
\hline D-Mannitol & - & - \\
\hline Inositol & - & - \\
\hline D-Sorbitol & - & - \\
\hline L-Rhamnose & - & - \\
\hline Saccharose & + & - \\
\hline Melibiose & - & - \\
\hline Amygdamin & - & - \\
\hline Arabinose & + & - \\
\hline
\end{tabular}

Pseudomonas cepacia の16SrDNA の配列と同一であっ た。電子頼微鏡による形態観察の結果，両菌株とも桿菌 で、菌の大きさは $1.5 \mu \mathrm{m} \times 0.5 \mu \mathrm{m}$ であった(Fig. 1)。 またAPI簡易同定キットの結果，再菌株ともグラム陰性 であるが，硣素活性及び炭素源の利用性に差異が認めら れた (Table 1)。

以上より，N-21株及び $\mathrm{N}-22$ 株は，いずれも Pseudomonas cepaciaに属する異なる囷株であることが わかった。

\section{$3.2 \mathrm{Nap}$ 分解菌の炭案資化性}

N-21株及びN-22株の培養を開始してから2日後に 培養液が混濁し始め,一週間後の菌数はNap を含んでい ない対照 $\left(3.4 \times 10^{7} \mathrm{cells} \cdot \mathrm{m} l^{-1}\right)$ と比較して N-21株 は約100倍 $\left(313 \times 10^{7}\right.$ cells $\left.\cdot \mathrm{ml}^{-1}\right) ， \mathrm{~N}-22$ 株は約40倍 $\left(126 \times 10^{7} \mathrm{cells} \cdot \mathrm{m} l^{-1}\right)$ に增加した。この結果により， 両株とも Nap を炭素源として増殖できることが確認さ
れた。

\subsection{Nap 分解菌によるNap 分解臬度}

両秼ともグルコース及びポリペプトン前培養において も Nap 分解能が見られたが，Nap 前培養によりその速 度は增加した。そのときの両株によるNap 濃度の経時的 な減少をFig. 2 に示した。培養初期過程における Nap の分解速度を 0 次反応と仮定してグルコース及びポリペ プトン前培湌菌と Nap 前培湌菌の間の差をとり,菌の初 期濃度が $1 \times 10^{8} \mathrm{cells} \cdot \mathrm{m} l^{-1}$ の場合の Napの分解速 度定数を求めたところ，N-21株 (Fig。2A) 及びN-22株 (Fig. 2B) とも $2.24 \times 10^{-5} \mathrm{M} \cdot \mathrm{h}^{-1}$ であった。

\section{4 代謝物の同定と経時变化}

Nap を添加した分離培地にN-21株あるいはN-22株 を加えて33.5時間培養した液の HPLCクロマトグラム をFig. 3 に示した。N-21株の培養液加らは，Nap以外

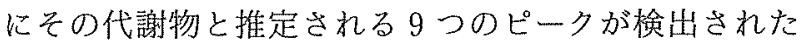



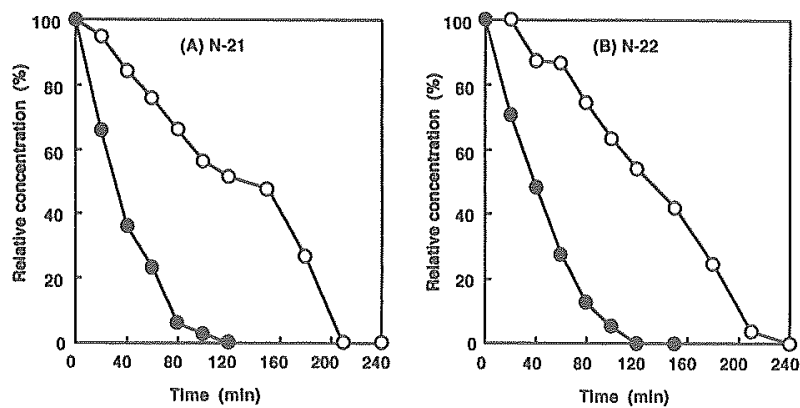

Fig. 2 Time Courses of Naphthalene Concentrations in the Presence and Absence of (A) N-21 and (B) N -22 Strains

$\bigcirc$, precultured in glucose/polypepton-containing medium; precultured in naphthalene containing medium.

(A)

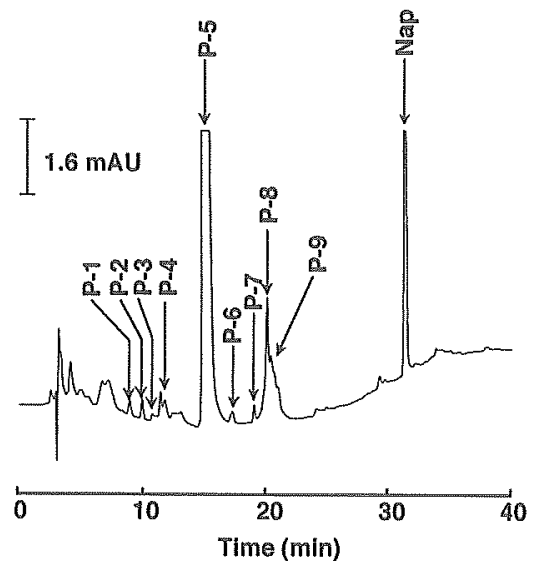

(Fig. 3A)。一方，N-22株の培養漼加らは，Nap 以外に その代謝物と推定される11のピークが検出された（Fig. 3B）。これらのピークについて推定される化合物標品の 保持時間，最大吸収波長，質量分析におけるべースイオ ンをTable 2 に示した。標品の保持時間と比較したと き,N-21株及びN-22株試料の HPLC ピークのなかには 標品の保持時間とわずかにずれが生じるものがあった が，標品を試料に添加したときのピークの一致，UV 吸収 スペクトルの一致及び質量スペクトルの一致から，いず れの菌株の培養液からもシスー1,2-ジヒドロ-1,2-ナフタ レンジオール(それぞれ Fig. 2A，B の P-5，P-V)，サ リチルアルデヒド (P-7，P-VII)，サリチル酸 (P-9， $\mathrm{P}-\mathrm{X})$ ，ゲンチシン酸 $(\mathrm{P}-4 ， \mathrm{P}-\mathrm{IV})$ を同定できた。力 テコールについては，N-22株の培養液から同定された (P-II）が，N-21株の培養液からは同定できなかった。 N-21株及びN-22株によるNap 代謝物ピークの消長 をFig. 4 に示した。Nap 分解による主代謝生成物はN

(B)

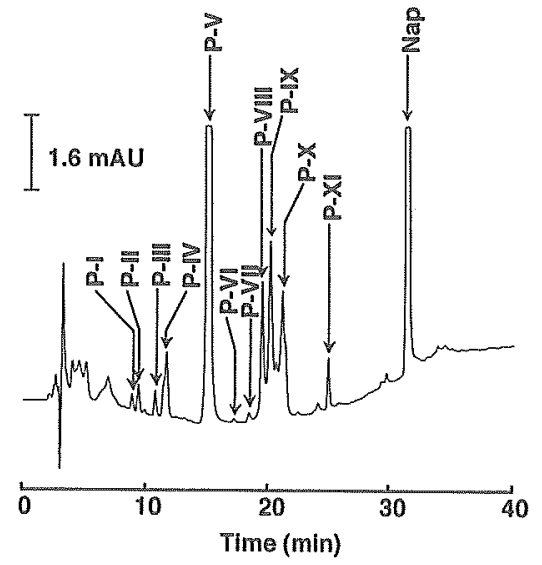

Fig. 3 Typical Chromatograms of Incubation Mixtures of Naphthalene and (A) N -21 and (B) N-22 Strains

Initial conditions: naphthalene, $19.5 \mathrm{mM}$; bacterium, $1 \times 10^{-6}$ cells $\cdot \mathrm{m} l^{-1}$. Incubation conditions: temperature, $27^{\circ} \mathrm{C}$; incubation time, $33.5 \mathrm{~h}$. HPLC conditions : column, Cosmosil 5C18-MS (4.6 mm i. d. $\times 25 \mathrm{~cm})$; mobile phase, acetic acid (pH 3.0) - methanol, from $20 \%(0 \mathrm{~min})$ to $90 \%(30 \mathrm{~min})$ methanol ; flow rate, $1.0 \mathrm{~m} l \cdot \mathrm{min}^{-1}$; detection, $275 \mathrm{~nm}$.

Table 2 Identification of HPLC Peaks of Naphthalene Metabolites by UV Spectra and Mass Spectra

\begin{tabular}{|c|c|c|c|c|c|c|c|c|c|c|c|}
\hline \multirow{2}{*}{\multicolumn{4}{|c|}{ Standard }} & \multirow{2}{*}{\multicolumn{8}{|c|}{ Test mixture }} \\
\hline & & & & & & & & & & & \\
\hline Compound & $\begin{array}{l}\text { Rt } \\
\text { min }\end{array}$ & $\begin{array}{l}\text { UV spectra } \\
\text { Max (nm) }\end{array}$ & $\begin{array}{l}\text { Mass spectra } \\
\text { Base ion }(\mathrm{m} / \mathrm{z})\end{array}$ & Peak $^{a)}$ & $\begin{array}{l}\mathrm{Rt} \\
\min \end{array}$ & $\begin{array}{l}\text { UV spectra } \\
\text { Mas (nm) }\end{array}$ & $\begin{array}{l}\text { Mass spectra } \\
\text { Base ion }(\mathrm{m} / \mathrm{z})\end{array}$ & Peak $^{a)}$ & Rt & $\begin{array}{l}\text { UV spectras } \\
\text { Max (nm) }\end{array}$ & $\begin{array}{l}\text { Mass spectra } \\
\text { Base ion }(\mathrm{m} / \mathrm{z})\end{array}$ \\
\hline Catechol & 9.0 & 216,276 & $109[\mathrm{M}-\mathrm{H}]^{\circ}$ & & & & & P-II & 8.7 & & 109 \\
\hline Gentistic acid & 11.7 & 236,328 & $153[\mathrm{M}-\mathrm{H}]^{-}$ & p.4 & 11.9 & & 153 & P-IV & 11.9 & & 153 \\
\hline $\begin{array}{l}c i s-1,2 \text {-Dihydro- } \\
\text { 1,2-naphthalenediol }\end{array}$ & $1^{14.6}$ & 216,260 & $145[\mathrm{M}+\mathrm{H} 2 \mathrm{O}]^{+}$ & P.5 & 14.7 & 216,264 & 145 & P.V & 14.7 & 216,264 & 145 \\
\hline Salicylaldehyde & 18.0 & 256,324 & $121[\mathrm{M}-\mathrm{H}]^{*}$ & P-7 & 18.5 & & & P.VII & 18.5 & & \\
\hline Salicylic acid & 21.7 & 236,300 & $137[\mathrm{M}-\mathrm{H}]^{"}$ & $P-9$ & 21.7 & 236,300 & 137 & P.X & 21.7 & 236,300 & 137 \\
\hline
\end{tabular}

a) Numbers $4-9$ and II- $X$ mean peaks on chromatograms $A$ and $B$ in Fig. 2, respectively. 

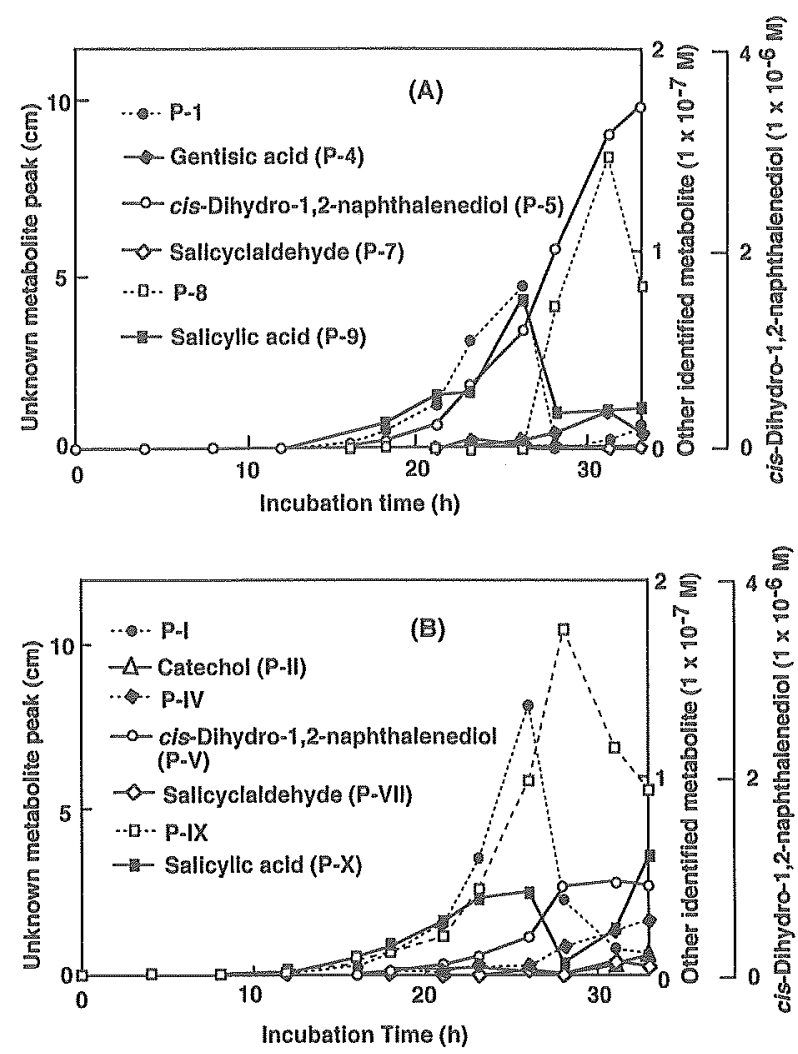

Fig. 4 Time Courses of Peak Heights of Naphthalene Metabolites in the Presence of (A) N-21 and (B) N -22 Strains

Initial conditions: naphthalene, $19.5 \mathrm{mM}$; bacterium, $1 \times 10^{-6}$ cells $\cdot \mathrm{m} l^{-1}$. Incubation temperature, $27^{\circ} \mathrm{C}$.

-21株（Fig.4A）及びN-22株（Fig.4B）ともシス -1,2-ジヒドロ-1,2-ナフタレンジオールであり, 同定さ れた他の代謝物と比べて最高濃度は 5 ～20倍程度高かっ た。これはシス-1,2-ジヒドロ-1,2-ナフタレンジオ一ル が，Nap 代謝で最初に生成される化合物であり，その生 成速度に比べて分解速度が遅く，この段階が Nap 代謝に おける律速過程となっているためと考えられる。

N-21株の培養液で未同定の代謝物ピークのうち HPLCによるピーク高さの経時変化が追跡可能であっ た P-1，P-8については早い方からこの順番に最高濃 度に達した。N-22株の培養液でもそれそれれと同一の保持 時間を有する P-I，P-IXが観察され，早い方からこの䐓 番に最高濃度に達した。この結果も，両菌株による代謝 が同一の機序によることを示晙している。

N-21株，N-22株のいずれの HPLCクロマトグラムに おいても未同定ピークは多くなく、同定された Nap 代謝 物の蒡造及びそれらの濃度の時間経過の追跡結果から， Napの主代謝経路を Fig.50ように推定した。この経 路は，好気条件下で推定されている経路 ${ }^{16)}$ と同一であっ た。

\subsection{Nap 及びその代謝物の变異原性}

一般に，Ames 試験において多くのPAH は塩基対置 換型の変異原性を有するので, S. typhimurium TA98株 よりもTA100株を用いた方がより強い変異原性が現れ る5)。そこで，TA100株を使用し，加つ生菌数による補正 を施して Nap の直接変異原性と間接変異原性を測定し

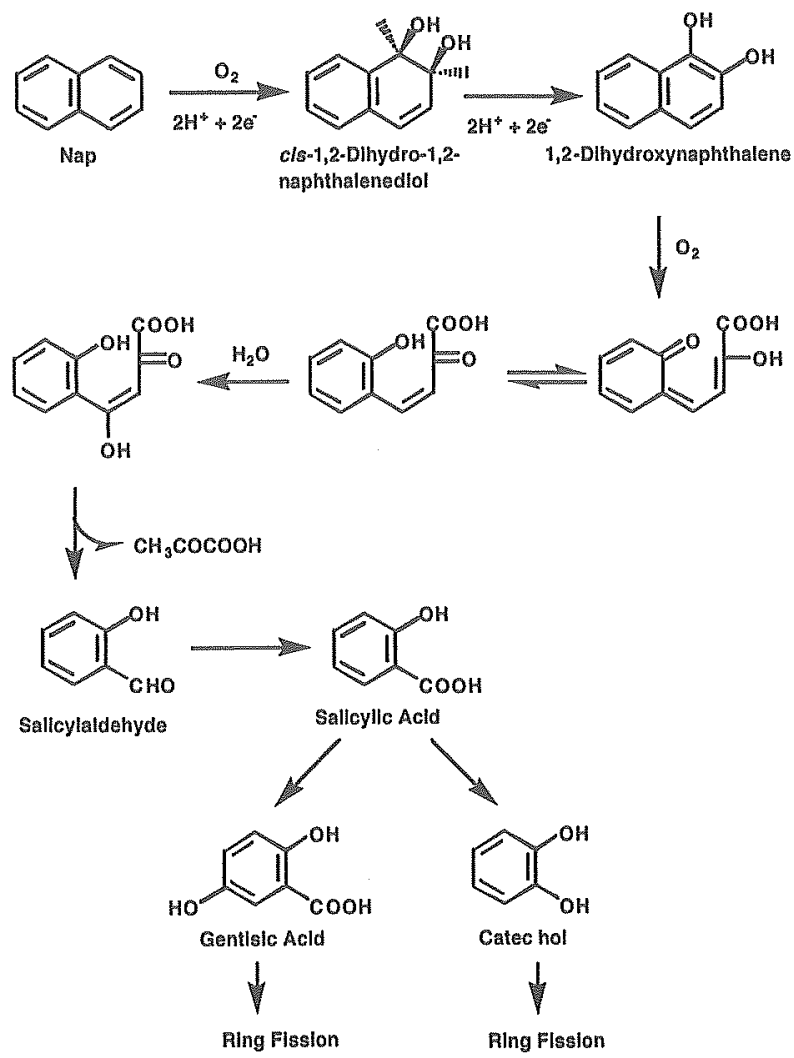

Fig. 5 Proposed Pathway for Methabolism of Naphthalene in N-21 and N-22 Strains

た結果っこれまで変異原性が報告されていないNapに弱 いながら間接変異原性（+S9mix）が認められた (Table 3)。しかし，N-21株あるいはN-22株の培養液か ら同定されたシス-1,2-ジヒドロ-1,2-ナフタレンジオー ル，サリチルアルデヒド，サリチル酸，ゲンチシン酸， カテコールの Ames 試験の結果，いずれも対照と比較し て有意な差はみられなかった。さらに，いずれの菌株の 培養液についても, 有為な変異原性は認められなかった (Table 4)。

以上の Table 3 及び Table 4 の結果より，N-21株及 びN-22株によるNap 代謝は，Napの変異原性の低下に 有効であることがわかった。

\section{4.まとぬ}

本研究では土壤中から Nap 分解菌 N-21株及び N-22 株を単離し，その Nap 分解機序と生成した代謝物の変異 原性について調べた。結果は以下のとおりであった。

1) N-21株及びN-22株はいずれも Pseudomonas cepaciaに属する巽なる菌株であった。

2）N-21株及びN-22株はともにNap を炭素源とし て利用した。

3） N-21株及びN-22株によるNap 分解速度はとも に2.24× $10^{-5} \mathrm{M} \cdot \mathrm{h}^{-1 て ゙ あ っ た 。 ~}$

4) N-21株及びN-22株によるNap 分解では，とも にシス-1,2-ジヒドロ-1,2-ナフタレンジオールが主代謝 生成物であり，サリチルアルデヒド，サリチル酸，ゲン テシン酸,カテコールの生成も確認された。

5) Nap はN-21株及びN-22株に代謝されると変異 原性は低下した。 
Table 3 Ames Test of Naphtalene Metabolites in the S. typhimurium TA100 Strain

\begin{tabular}{|c|c|c|c|c|c|}
\hline \multirow{2}{*}{ Compound } & \multirow{2}{*}{$\begin{array}{c}\text { Concentration } \\
(\mu \mathrm{g} / \mathrm{plate})\end{array}$} & \multicolumn{2}{|r|}{$-\mathrm{s} 9 \mathrm{mix}$} & \multicolumn{2}{|r|}{$+\mathrm{S} 9$ mix } \\
\hline & & Revertant & Conrected revertant $^{\mathrm{a})}$ & Revertant & Corrected revertant ${ }^{a)}$ \\
\hline Control & & 100 & 100 & 100 & 100 \\
\hline \multirow[t]{3}{*}{ Naphthalene } & 20 & 111 & - & 145 & 152 \\
\hline & 40 & 119 & - & 147 & 196 \\
\hline & 100 & 132 & . & 94 & $345^{b)}$ \\
\hline \multirow[t]{3}{*}{ Catecol } & 20 & 118 & 70 & 130 & 74 \\
\hline & 40 & 101 & 69 & 144 & 75 \\
\hline & 100 & 126 & 109 & 135 & 67 \\
\hline cis-1,2-Dihidro- & b- 20 & 125 & - & 120 & 58 \\
\hline 1,2-naphthalene- & e. 40 & 139 & 174 & 183 & 69 \\
\hline diol & 100 & 155 & - & 143 & 52 \\
\hline \multirow[t]{3}{*}{ Gentisic acid } & 20 & 90 & 54 & 119 & 64 \\
\hline & 40 & 89 & 48 & 119 & 70 \\
\hline & 100 & 99 & 60 & 138 & 67 \\
\hline \multirow[t]{3}{*}{ Salicilic acid } & 20 & 107 & 79 & 105 & 108 \\
\hline & 40 & 93 & 76 & 150 & 147 \\
\hline & 100 & 78 & 73 & 74 & 84 \\
\hline \multirow[t]{3}{*}{ Salicylaldehyde } & 20 & 113 & 73 & 122 & 127 \\
\hline & 40 & 122 & 94 & 133 & 120 \\
\hline & 100 & 110 & 121 & 60 & 57 \\
\hline
\end{tabular}

a) Corrected Revertants $=$ Revertants $\mathrm{x}$ (alive cell numbers of control sample / alive cell numbers of test sample). b) Correct revertant $>200$.

Table 4 Ames Test of Naphtalene-Bacteria Mixtures in the S. typhimurium TA100 Strain

\begin{tabular}{llcc}
\hline \multirow{2}{*}{ Bacteria } & Dilution ratio & \multicolumn{2}{c}{ Corrected Revertant } \\
\cline { 3 - 4 } & & - S9mix & + S9mix \\
\hline Control & & 100 & 100 \\
N-21 & 1 & 138 & \\
& $1 / 3$ & 85 & 181 \\
& $1 / 10$ & 123 & 147 \\
& & & 140 \\
N-22 & 1 & 147 & 90 \\
& $1 / 3$ & 123 & 120 \\
& $1 / 10$ & 100 & 140 \\
\hline
\end{tabular}

Initial concentration of naphthalene in the mixture, $19.5 \mathrm{mM}$.

(原稿受付 2000 年 9 月 6 日) (原稿受理 2000年11月 7 日)

\section{參考 文 嗝}

1)松下秀鶴（1984）大気污染物質レビュー 多環芳香族炭化水 素，河合清之編，環境庁委託業務結果報告畫，303-356.

2) 川田邦明, 横山ひろみ, 森山 登, 白井文雄（1988） 中小河川 底質中の芳香嗾炭化水素の分布，衛生化学，34，248-255.

3) Spitzer, T. and Kuwatsuka, S. (1993) Residue Levels of Polynuclear Aromatic Compounds in Urban Surface in Japan. J. Chromatogr, 643, 305-309.

4) 川中 聡, 北畠干嗣, 田井和夫 (1998) 多謤芳香族分解菌の単 離とその分解特性の比較，水環境学会誌，21，429-436。

5 ) 木津良一, 安藤京子, 早川和一（1998） 日本海重油流出事故, 衛生化学, 44, 321-333.
6) U.S. Department of Health and Human Services (1990) Toxicological Profile for Naphthalene and 2-Methylnaphthalene (Draft).

7) U.S. Environmental Protection Agency (1986) Health and Environmental Effects Profile for Naphthalene, EPA/600/x $-86 / 241$.

8) U.S. Department of Health and Human Services (1993) Hazardous Substances Data Bank (HSDB, online database).

9) U.S. Environmental Protection Agency (1986) Health Effects Assessment for Naphthalene, EPA/540/1-86/014.

10) U.S. Environmental Protection Agency (1993) Integrated Risk Information System (IRIS) on Naphthalene.

11) Mueller, J.G., Chapman, P.J., Blattmann, B.O. and Pritchard, P.H. (1990) Isolation and Characterization of Fluoranthene -Utilizing Strain of Pseudomonus paucimobilis, Appl. Environ. Microbiol., 56, 1079-1086.

12) Heitkamp, M.A., Franklin, W. and Cerniglia, C.A. (1988) Pyrene Degradation by a Mycobacterium sp. : Identification of Ring Oxidation and Ring Fission Products, Appl. Environ. Microbiol., 54, 2549-2555.

13) Cerniglia, C.E. (1984) Microbial Metabolism of Polycyclic Aromatic Hydrocarbons, National Center for Toxicological Research, 30, 31-65.

14) Cookson, J.T. Jr. (1995) Bioremediation Engineering -Design and Application-, McGraw-Hill, Inc., New York.

15) Gupta, R., Lanter, J.M. and Woese, C.R. (1983) Sequence of the $16 \mathrm{~S}$ Ribosomal RNA from Halobacterium volcanii, and Archaebacterium, Science, 211, 656-659.

16) Gibson, D.T. and Subramanian, V. (1984) Microbial Degra dation of Aromatic Hydrocarbons, Microbial Degradation of Organic Compounds, Gibson, D.T. (Ed.), Marcel Dekker, New York, 181-252. 